\title{
Taxonomic note: transfer of Amoebobacter purpureus to the genus Pfennigia gen. nov., as Pfennigia purpurea comb. nov., on the basis of the illegitimate proposal to make Amoebobacter purpureus the type species of the genus Amoebobacter
}

\author{
B. J. Tindall \\ Tel: +495312616 224. Fax: +495312616 418. e-mail: bti@dsmz.de
}

DSMZ - Deutsche Sammlung von Mikroorganismen und Zellkulturen $\mathrm{GmbH}$, Mascheroder Weg 1b, D-38124 Braunschweig, Germany
Keywords: taxonomy, Amoebobacter purpureus, Pfennigia purpurea, Bacteriological Code
In a recent article dealing with the taxonomy of members of the genera Thiocapsa and Amoebobacter, Guyoneaud et al. (1998) have proposed that several species of the genus Amoebobacter should be transferred to the genus Thiocapsa. Among those species transferred to the genus Thiocapsa was the type species of the genus Amoebobacter, Amoebobacter roseus. In formally considering that Amoebobacter roseus, the type of the genus Amoebobacter (Winogradsky $1888^{\mathrm{AL}}$ ), should be placed in the genus Thiocapsa, the authors have also sought to place the remaining species from the genus Amoebobacter in other genera. Apart from the transfer of Amoebobacter roseus to the genus Thiocapsa, as Thiocapsa rosea, and the proposal of a new genus Thiolamprovum (Guyoneaud et al., 1998) to accommodate Amoebobacter pedioformis, the authors left Amoebobacter purpureus as the only species within the genus Amoebobacter. In view of the fact that the type species of this genus was placed in the genus Thiocapsa (Winogradsky $1888^{\mathrm{AL}}$, emend. Guyoneaud et al. 1998), Guyoneaud et al. (1998) proposed that Amoebobacter purpureus be elevated to the status of type species for the genus Amoebobacter (Winogradsky $1888^{\mathrm{AL}}$, emend. Guyoneaud et al. 1998). The Bacteriological Code (Lapage et al., 1992) states quite explicitly that the type "is that element of the taxon with which the name is permanently associated' (Rule 15). As a result the proposal to create a new type species for the genus Amoebobacter (Winogradsky $1888^{\mathrm{AL}}$, emend. Guyoneaud et al. 1998) is 'contrary to the Rules' [Rule 23a (ii)]. A name which is contrary to the Rules is illegitimate. Principle 8 states that 'each order or taxon of a lower rank with a given circumscription and rank can bear only one correct name, i.e., the earliest that is in accordance with the
Rules of this Code', while Rule 23b states that 'for the purpose of priority only, legitimate names and epithets are taken into consideration'. The correct name of a taxon is based upon valid publication, legitimacy and priority of publication (Principle 6). Although the species Amoebobacter purpureus has priority within the genus Amoebobacter (Winogradsky $1888^{\mathrm{AL}}$ ) in which the type species is Amoebobacter roseus, the proposal to make Amoebobacter purpureus the type species of the genus Amoebobacter (Winogradsky $1888^{\mathrm{AL}}$, emend. Guyoneaud et al. 1998) is illegitimate, and as such has no claim to priority, nor can it be considered to be correct.

Considering that the authors present evidence that this organism warrants inclusion within a genus separate from Thiocapsa rosea (basonym: Amoebobacter roseus), they are not at liberty to change the type species of the genus Amoebobacter (Winogradsky $1888^{\mathrm{AL}}$ ), nor is the publication of an emended description of the genus Amoebobacter (Winogradsky $1888^{\mathrm{AL}}$ emend. Guyoneaud et al. 1998), in which a new type species is designated, consistent with the Rules of the Bacteriological Code. Irrespective of the taxonomic position of Thiocapsa rosea or Amoebobacter roseus, the species Amoebobacter purpureus should be placed in a different genus to Amoebobacter (Winogradsky $1888^{\mathrm{AL}}$ ), Thiocapsa (Winogradsky $1888^{\mathrm{AL}}$, emend. Guyoneaud et al. 1998) or Thiocapsa (Winogradsky $1888^{\mathrm{AL}}$ ). In order to solve the confusion caused by this publication, it is proposed that Amoebobacter purpureus be tranferred to a new genus, for which the name $P$ fennigia gen. nov. is proposed. The only species within this genus is the type species Pfennigia purpurea comb. nov. 


\section{Description of Pfennigia gen. nov.}

Pfennigia (Pfen.nig'ia. M.L. ending -ia; M.L. fem. n. Pfennigia named after Norbert Pfennig, in recognition of his contribution to the biology and taxonomy of anoxygenic phototrophic bacteria).

Cells are Gram-negative, non-motile and oval to spherical, $1.9-3.8 \times 2.0-4.5 \mu \mathrm{m}$. Large aggregates of cells (up to 40) may be formed. Growth may be photolithotrophic under anoxic conditions in the light, or chemoautotrophic under micro-oxic conditions in the dark. Electron donors used are sulphide, thiosulphate or elemental sulphur. During the oxidation of sulphide or thiosulphate to sulphate globules of elemental sulphur appear inside the cells. May not be capable of assimilatory sulphate reduction. Intracellular photosynthetic membranes are of the vesicular type. The major photosynthetic pigments are bacteriochlorophyll $a$ and the carotenoid okenone. The $\mathrm{G}+\mathrm{C}$ content of the DNA is $63.4-64.1 \mathrm{~mol} \%$ (buoyant density). 16S rDNA sequence analysis indicates that this genus is a member of the Thiocapsa-Thiolamprovum phyletic group within the $\gamma$-subclass of the Proteobacteria. The type species of the genus Pfennigia is Pfennigia purpurea comb. nov.
Description of Pfennigia purpurea comb. nov. (basonym: Amoebobacter purpureus Eichler and Pfennig 1988)

Pfennigia purpurea (pur.pur'ea. L. fem. adj. purpurea purple or purple-red).

The description of the species is identical to that given by Eichler \& Pfennig (1988). The type strain is DSM $4197^{\mathrm{T}}\left(=\right.$ strain ThSchl2 ${ }^{\mathrm{T}}=$ Schleinsee $\left.^{\mathrm{T}}\right)$.

\section{References}

Eichler, B. \& Pfennig, N. (1988). A new purple sulfur bacterium from stratified freshwater lakes, Amoebobacter purpureus sp. nov. Arch Microbiol 149, 395-400.

Guyoneaud, R., Süling, J., Petri, R., Matheron, R., Caumette, P., Pfennig, N. \& Imhoff, J. F. (1998). Taxonomic rearrangements of the genera Thiocapsa and Amoebobacter on the basis of $16 \mathrm{~S}$ rDNA sequence analyses and description of Thiolamprovum gen. nov. Int $J$ Syst Bacteriol 48, 957-964.

Lapage, S. P., Sneath, P. H. A., Lessel, E. F., Skerman, V. B. D., Seeliger, H. P. R. \& Clark, W. A. (editors) (1992). International Code of Nomenclature of Bacteria (1990 Revision). Bacteriological Code. Washington, DC: American Society for Microbiology. 